УДК 34.01:349

DOI https://doi.org/10.51989/NUL.2021.4.23

\title{
ПРАВОВА ГЕРМЕНЕВТИКА В МЕТОДОЛОГІЇ ДОСЛІДЖЕНЬ ТА ЮРИДИЧНІЙ АРГУМЕНТАЦІЇ НАУКИ ТРУДОВОГО ПРАВА I ПРАВА СОЦІАЛЬНОГО ЗАБЕЗПЕЧЕННЯ
}

\author{
Новіков Денис Олександрович, \\ кандидат юридичних наук, \\ доцент кафедри цивільно-правових дисциплін і трудового права \\ імені професора О. І. Процевського \\ Харківського національного педагогічного університету імені Г. С. Сковороди \\ Жукова Анна Iгорівна, \\ кандидат філософських наук, \\ доцент кафедри правового регулювання економіки \\ Харківського національного економічного університету імені Семена Кузнеця
}

У статті окреслюється місце правової герменевтики у методології досліджень та юридичній аргументації науки трудового права та права соціального забезпечення. Вказано, що при використанні правової герменевтики у методології юридичних досліджень та юридичній аргументації інтерпретаційна діяльність не обмежується дослідженням явища з точки зору його формально-логічного аналізу. Автори вважають, що правова герменевтика володіє методологічним інструментарієм, за допомогою якого можна не лише інтерпретувати та розуміти текст, але й пізнати автора тексту. Визначено, що інтерпретація тексту здійснюється із застосуванням методів як лінгвістики, так і філософії, зокрема подвійної і потрійної рефлексії. Зазначається, що інтерпретація тексту відбувається у межах так званого герменевтичного кола, в якому текст проходить декілька інтерпретаційних стадій: формування «передрозуміння» (звільнення від забобонів сприйняття та відкидання емоційного контексту), курсорне читання (виділення основних культурних і лінгвістичних символів тексту, пошук і виявлення «темних місць»), формулювання і перевірка гіпотез (надання відповідей на поставлені до «темних місць» питання та окреслення аргументів, котрі встановлюють зв'язки між текстом і інтерпретацією). Автори зазначають, що застосування засобів правової герменевтики для вивчення таких сучасних явищ науки трудового права і права соціального забезпечення передусім потрібне для відмежування їхнього реального смислу від стереотипів та зловживань так званого «передрозуміння», завчасного неприйняття нової конструкції через певні традиційні забобони класичної юридичної науки при збереженні нейтрального відношення. Автори переконані, що використання не лише класичного методологічного апарату, але й таких нетипових для вітчизняної юридичної науки засобів, як правова герменевтика, може створити фундамент для уникнення «передрозуміння» при дослідженні сучасних правових явищ, сформувати дослідницьке поле для винайдення універсальних підходів до регулювання трудових відносин і відносин у сфері соціального захисту.

Ключові слова: правова герменевтика, методологія, юридична аргументація, трудове право, право соціального забезпечення.

Novikov Denys, Zhukova Anna. Legal hermeneutics in the research methodology and legal argumentation of the science of labor law and social security law

The article outlines the place of legal hermeneutics in the research methodology and legal argumentation of the science of labor law and social security law. The authors point out that when using legal hermeneutics in the methodology of legal research and legal argumentation, interpretive activity is not limited to the study of the phenomenon in terms of its formal and logical analysis. The authors believe that legal hermeneutics has a methodological tool by which you can not only interpret and understand the text, but also get to know the author of the text. It is determined that the interpretation of the text is carried out using the methods of both linguistics and philosophy, in particular double and triple reflection. The authors note that the interpretation of the text takes place within the so-called hermeneutic circle, in which the text goes through 
several interpretive stages: the formation of "preconception" (liberation from prejudices and rejection of emotional context), cursor reading (highlighting the main cultural and linguistic symbols of the text identification of "dark places"), formulation and testing of hypotheses (providing answers to questions asked to the "dark places" and outlining the arguments that establish links between the text and interpretation). The authors note that the use of legal hermeneutics to study such modern phenomena of labor law and social security law is primarily needed to distinguish its real meaning from stereotypes and abuses of so-called "preconception", premature rejection of the new construction due to certain traditional prejudices of classical jurisprudence with saving of neutral attitude. The authors are convinced that the use of not only the classical methodological apparatus, but also such atypical for domestic legal science tools as legal hermeneutics, can create a foundation for avoiding "preconception" in the study of modern legal phenomena, form a research field for inventing universal approaches to labor relations and relations in the field of social protection.

Key words: legal hermeneutics, methodology, legal argumentation, labor law, social security law.

Постановка проблеми. Дослідження правових явищ на сучасному етапі розвитку юридичної науки через ускладнення соціально-економічних відносин, які детермінують трансформації у категоріальному апараті, потребує використання нетрадиційної методології пізнання. Однією із таких нетрадиційних методологій пізнання сучасних правових явищ $\epsilon$ герменевтика. Герменевтичний спосіб розуміння заснований на проникненні не лише в зовні виражений (об'єктивний), але й у суб'єктивний світ, коли тлумачення здійснюється з урахуванням позицій інтерпретатора та індивідуальних особливостей мови автора. Герменевтика у дослідженні правових явищ спрямована на усвідомлення правової дійсності в цілому, а не тільки на розуміння сутності позитивних правових приписів, зафіксованих у законодавстві. Означене $\epsilon$ дуже важливим на сучасному етапі розвитку методології юридичної науки загалом та, зокрема, методології досліджень у сфері трудового права і права соціального забезпечення, коли в теоретичних студіях із цих юридичних наук та у практиці ринку праці і соціального захисту з'являються нові категорії, котрі потребують не лише формальнологічного осягнення, але й з'ясування їх сутнісного смислу.

Аналіз останніх досліджень. Останніми роками проблематика правової герменевтики широко представлена в юридичній науці. Серед вітчизняних дослідників, які розглядали питання сутності та окремих аспектів правової герменевтики, треба зазначити А.М. Бернюкова [1; 2], I.B. Гетьман [3], Т.В. Міхайліну [4],
Я.Л. Москаленко [5], О.В. Нетреб'як [6], Н.I. Сатохіну [7], В.А. Трофименка [8], Ю.В. Цуркан-Сайфуліну [9], К.О. Шелестова [10]. Водночас відсутні дослідження, що стосуються використання інструментів правової герменевтики в науці трудового права та права соціального забезпечення. Окреслена зазначеними вище науковцями специфіка правової герменевтики заклала теоретичний фундамент для проведення цієї наукової розробки щодо визначення місця правової герменевтики у методології досліджень та юридичній аргументації науки трудового права та права соціального забезпечення.

Формулювання мети статті. Автори мають на меті визначити місце правової герменевтики у методології досліджень та юридичній аргументації науки трудового права та права соціального забезпечення.

Виклад основного матеріалу статті. Слово «герменевтика» походить із древньогрецької мови від дієслова hermenetikos, що в перекладі означає «інтерпретувати», «пояснювати», «відображати», а також від іменника hermeneia, який перекладається як інтерпретація. При використанні герменевтики інтерпретаційна діяльність не може обмежуватися дослідженням явища з точки зору його формально-логічного аналізу. Насамперед потребує вивчення текст, в якому було викладене уявлення про явище, причому інтерпретація тексту повинна здійснюватися із застосуванням методів як лінгвістики, так і філософії, зокрема подвійної і потрійної рефлексії, за якими об'єктом пізнання може бути сам спосіб пізнання, а також знання, думка або вчинок. 
Для здійснення пізнання шляхом множинної рефлексії певного явища герменевти застосовують герменевтичне коло. Його завдання полягає у тому, щоб осягнути ціле і водночас збагнути окремі його гомогенні (однорідні) і гетерогенні (різнорідні) частини і навпаки. Себто герменевтичне коло відображає процес, в основу якого покладене постійне виникнення й розв'язання суперечностей між цілим і частинами, уточнюваними на підставі цілого. Це у жодному разі не зводиться до простого замінювання компонентів чи напрямків руху по колу, а радше спонукає щоразу повертатися від окремого до загального й навпаки.

При входженні у герменевтичне коло чи під час перебування в ньому слід дотримуватися настанови, аби різні уявлення про текст були не випадковими, викривленими, упередженими чи хибними, аби в основу тлумачення покладалися факти. Герменевту, пам'ятаючи, що об'єкт не залежить від факту існування теорій, прагнучи осягнути текст, необхідно передусім зробити первинне окреслення смислу (передрозуміння), котрий поступово вимальовується у тексті, і насамкінець узагальнити загальний смисл явища. Герменевтичне коло передбачає, що лише одночасне бачення одиничного, особливого та загального дозволяє наблизитися до адекватного прочитання тексту. Як бачимо, завдання герменевтики полягає не у розімкненні герменевтичного кола, а в тому, аби у нього увійти і зрозуміти його специфіку.

Здійснюючи характеристику основних інструментів для роботи у герменевтичному колі, зупинимось на сучасних явищах науки трудового права і права соціального забезпечення та на наукових текстах, котрі їм присвячені. Отже, герменевтичне коло проходить такі етапи.

1. Формування «передрозуміння». «Передрозуміння» - це первинне знайомство читача з текстом. Для читача це може бути розгляд обкладинки книги, прочитання анотації, рецензії на текст, рекомендація про текст від автора або іншої особи тощо. Найчастіше під час прочитання інтерпретація відбувається інтуїтивно, без технології і майже без втручання критичного мислення, яке біль- шою мірою замішано на враженні, переживанні, на синтезі отриманих смислів із власним досвідом. Процес одержання цих смислів не контролюється, і вірогідність їх найчастіше не перевіряється аналітично. Проте і в такому випадку можливий конфлікт інтерпретацій, тому що, хоча процес інтерпретації у сенсі техніки, здавалося 6, відсутній і замінений інтуїтивним розумінням, але після прочитання читач має інтерпретацію-результат - той образ тексту й смислу, який він може переказати своїми словами. Основною причиною можливих конфліктів інтерпретацій у цьому випадку, як правило, $\epsilon$ різні забобони і особистий досвід, покладений в основу цього інтуїтивного розуміння, які фільтрують текст, пропускаючи тільки частину можливих смислів.

Відповідно, основне, що здійснюється на цьому етапі - це «очищення» свідомості інтерпретатора від забобонів, котрі закріплені в особистому досвіді герменевта. Як правило, вони не рефлектуються та не усвідомлюються і слугують своєрідним фільтром та читацьким контекстом, через який проходить текст при прочитанні. Тому термін «забобони» треба брати його без специфічних негативних конотацій, у нейтральному аспекті. Варто відзначити, що частина забобонів про текст уже $\epsilon$ передрозумінням тому, що створює якесь вихідне уявлення про цілий текст і надає можливість входження в герменевтичне коло і просування до розгляду частин і коректування цього уявлення.

Як приклад, можна навести характеристику такому явищу трудового права як «гнучкість», котру надає Т.В. Парпан: «тенденції сучасного ринку праці вимагають від трудового законодавства більшої гнучкості для суб'єктів трудових правовідносин. Саме флексибілізація трудових правовідносин - це той напрям розвитку трудового законодавства, який на сьогодні має стати найбільш перспективним та бажаним і який допоможе оптимально поєднати економічну ефективність та соціальний прогрес» [11, с. 167]. У даному тексті відсутня аргументація щодо висновку про позитивні наслідки посилення гнучкості регулювання трудових відносин. При цьому можна побачити власне ставлення автора до предмету дослідження, 
в якому виражена думка про можливість безболісного поєднання ринкових інструментів та соціальної складової трудового законодавства.

Або навпаки: автори цієї статті у публікації, присвячений проблематиці гнучкості у трудовому праві, писали, що «гнучкість не може бути поставлена у служіння економічним інтересам окремих сил міжнародного капіталу. Для трудового права у сучасних умовах важливе збереження впливу на правове регулювання у сфері праці на засадах свободи та справедливості, що передбачає забезпечення у нормах права загальнонародного інтересу» [12, с. 201]. Треба визнати, що з точки зору герменевтичних засобів така позиція теж сповнена забобонів «передрозуміння» через визнання певних ціннісних орієнтирів науки трудового права, а не дослідження явища. Крім того, адресованість такої статті певній аудиторії, що знається на проблемах трудового права, створює додаткові забобони до реального розуміння написаного. Себто науковець з трудового права зовсім по-різному буде сприймати ту ж статтю про гнучкість регулювання трудових відносин, ніж вченийцивіліст. Водночас перед прочитанням тексту можна спробувати налаштувати процес майбутнього розуміння через рефлексію власних установок та вибір операційних установок, з огляду на які планується інтерпретувати текст. Це називається вибором між герменевтикою довіри та герменевтикою підозри. Людині, схильній довіряти написаному, буде непросто «увімкнути» установку на сумнів і критику, але це цілком можливо. Крім того, можна перебороти недовіру до конкретних джерел, зібрати додаткову інформацію про текст, що також буде служити базою для розуміння.

2. Курсорне читання. При курсорному читанні текст прочитується рівномірно, без затримок і міркувань над конкретними частинами, для того, щоб охопити ціле, якщо мова йде про прочитання тексту загалом, або для того, щоб сформулювати вихідні припущення, щоб дати поштовх подальшому просуванню в глибину тексту й увійти в герменевтичне коло. На цій стадії виділення смислу відбувається «природним» шляхом, мовні (або інші симво- лічні) конструкції тексту фільтруються контекстом забобонів читача, у результаті чого формується розуміння, що може бути трансформоване в інтерпретацію. Тут багато залежить від особистого досвіду інтерпретатора і його вміння «вчитуватися» у текст, співвідносити його із власним досвідом. Також відбувається виявлення «темних місць» - слів, символів або ділянок тексту, що викликають утруднення в розумінні, емоційну реакцію або інтуїтивно притягають увагу як більш значимі місця стосовно іншого полотна тексту. Це можуть бути незрозумілі слова або сполучення слів, відсутні на перший погляд зв'язки між частинами тексту, дивні оцінки у тексті, що підвищують емоційний стан читача тощо.

Проілюструємо виявлення «темних місць» при курсорному читанні у розрізі опису в наукових текстах такого явища у дослідницьких студіях права соціального забезпечення, як «безумовний базовий дохід» (далі - ББД). Так, Я.Ю. Завацька, оцінюючи це явище, вказує, що «вже зараз держава фінансує багатьох підприємців, доплачуючи допомогу до дуже низької зарплати їхніх працівників. ББД збільшить цю тенденцію. Навіть в ідеальному варіанті він являє той самий перерозподіл замість того, щоб гідно оплачувати працю своїх працівників, капіталіст віддає державі великий податок, що піде на утримання цих людей» [13]. Як бачимо, цей текст є емоційно забарвленим з акцентом на пригнічення слабких та володарювання багатих, містить неконкретні та оціночні відомості («багатьох підприємців», «дуже низької зарплати», «великий податок»), представляє читачу категоричні стратегії розвитку («збільшить цю тенденцію»). Наведене при курсивному читанні формує знану кількість «темних плям», котрі були виділені вище і які мають бути перевірені інтерпретатором разом із виділенням продуктивних місць. На цьому етапі герменевт має застосувати саморефлексію - діалог із самим собою, щоб здійснити аналітичну перевірку тексту на істинність. У своєму дослідженні [14] один з авторів цієї статті провів означену операцію із публікацією Я.Ю. Завацької та виокремив ключові висновки з інтерпретації теорії безумовного базового доходу з тексту дослідниці. 
3. Формулювання і перевірка гіпотез. Під час формулювання гіпотез (відповідей на поставлені до «темних місць»питання) включається творче мислення та інтуїція. Відбувається тонке балансування між пропозицією «перших» варіантів та інтерпретацією та пошуком найбільш дивних і несподіваних гіпотез. Чим більше різноманітних варіантів буде, тим повнішою й глибшою може у підсумку вийти інтерпретація. На цій стадії можуть формулюватися найбільш неймовірні на перший погляд гіпотези, які навіть можуть суперечити одна одній, але конфлікт між ними не передбачається - він наступає на стадії перевірки. Наприклад, те, що «гнучкість» одночасно може виступати як звуженням трудових прав працівників, так і інструментом покращення добробуту і рівня зайнятості трудящих, або те, що «безумовний базовий дохід» несе в собі загрозу системі соціального забезпечення і при цьому володіє значним звільняючим потенціалом для особистості та її творчих нахилів.

Надалі провадиться перевірка висунутих гіпотез. Ця перевірка будується на формальній логіці, виявленні адекватних зв'язків між текстом і інтерпретацією та пошуком аргументів як внутрішньотекстових, так і контекстуальних. Одним 3 найбільш ефективних способів перевірки $€$ конфлікт інтерпретацій, зокрема, доведення його до формування двох крайніх взаємовиключних позицій. Варто враховувати, що модельована дискусія має своїм завданням «пошук істини», а не тренування навичок аргументації. Основними інструментами тут служать логіка, здоровий глузд, спостережливість, сумлінність та звернення до фактів об'єктивної реальності, а не відсилання до суб'єктивних асоціацій, інтуїції і відчуттів читача. Опис власних вражень і асоціацій від прочитання тексту не варто плутати з його інтерпретацією.

Наприкінці проведення тексту через означені стадії провадиться синтез або вихід на нову спіраль герменевтичного кола. Відбувається об'єднання перевірених і прийнятих як достовірних та ймовірних гіпотез, пошук загального та співвіднесення з розумінням тексту як цілого. Через синтез ряду інтерпретацій, спрямо- ваних на прояснення та осмислення частин тексту, знову відбувається перехід до розуміння цілого, його доповнення і коректування та нового потрапляння у герменевтичне коло, з чого можна знову починати герменевтичну процедуру із наявним початковим розумінням тексту, щоб далі заглиблюватися в його деталі й нюанси. Отримана у результаті проробленої процедури інтерпретація може бути знову «знижена» до статусу передрозуміння, і поглиблення у текст почнеться знову.

Висновки. Під час використання правової герменевтики у методології юридичних досліджень та юридичній аргументації інтерпретаційна діяльність не обмежується дослідженням явища з точки зору його формально-логічного аналізу. Відповідно, правова герменевтика володіє методологічним інструментарієм, за допомогою якого можна не лише інтерпретувати та розуміти текст, але й пізнати автора тексту. Інтерпретація тексту здійснюється із застосуванням методів як лінгвістики, так і філософії, зокрема подвійної і потрійної рефлексії, за якими об'єктом пізнання може бути сам спосіб пізнання, а також знання, думка або вчинок. Інтерпретація тексту відбувається у межах так званого герменевтичного кола, в якому текст проходить декілька інтерпретаційних стадій: формування «передрозуміння» (звільнення від забобонів сприйняття та відкидання емоційного контексту), курсорне читання (виділення основних культурних і лінгвістичних символів тексту, пошук і виявлення «темних місць»), формулювання і перевірка гіпотез (надання відповідей на поставлені до «темних місць» питання та окреслення аргументів, котрі встановлюють зв'язки між текстом і інтерпретацією). Надалі герменевтичне коло зі всіма виділеними стадіями може повторюватись нескінченну кількість разів для повного пізнання смислу тексту та окреслених у ньому аргументів.

Застосування засобів правової герменевтики для вивчення сучасних явищ науки трудового права і права соціального забезпечення передусім потрібне для відмежування їх реального смислу від стереотипів та зловживань так званого «передрозуміння», завчасного неприйняття нової конструкції через певні традиційні 
забобони класичної юридичної науки при збереженні нейтрального відношення. Тому використання не лише класичного методологічного апарату, але й таких нетипових для вітчизняної юридичної науки засобів, як правова герменевтика, може створити фундамент для уникнення «передрозуміння» при дослідженні сучасних правових явищ, сформу- вати дослідницьке поле для винайдення універсальних підходів до регулювання трудових відносин і відносин у сфері соціального захисту. У подальших дослідженнях автори вбачають актуальним продовження вивчення методологічного потенціалу правової герменевтики через осмислення провідних текстів сучасної юридичної науки.

\section{ЛITEPATУPA:}

1. Бернюков А.М. Основний зміст правової герменевтики Артура Кауфмана. Юридична наука. 2016. № 1. С. 7-15.

2. Бернюков А.М. Юридична герменевтика як методологія здійснення правосуддя (філософсько-теоретичний аналіз): Автореф. дис. ... канд. юрид. наук : 12.00.12. Філософія права. Львів : Львівський державний університет внутрішніх справ, 2008. 18 с.

3. Гетьман I.В. Правова герменевтика і адаптація законодавства України в умовах становлення європейського правового простору. Вісник Академії правових наук України. 2012. № 4. С. 43-51.

4. Міхайліна Т.В. Акцентуалізація правосвідомості у площині правової герменевтики. Право і суспільство. 2017. № 6. С. 35-40.

5. Москаленко Я.Л. Герменевтика та праворозуміння (до питання про підходи до вивчення проблеми). Держава і право. Юридичні і політичні науки. 2014. № 65. С. 45-51.

6. Нетреб'як О. Сутність та значення правової герменевтики. Підприємництво, господарство і право. 2017. № 5. С. 189-192.

7. Сатохіна Н.І. Правова герменевтика між універсалізмом і контекстуалізмом. Філософія права і загальна теорія права. 2013. № 1. 169-179.

8. Трофименко В.А. Сучасна юридична герменевтика як механізм тлумачення принципів і цінностей у праві. Вісник Національної юридичної академії України імені Ярослава Мудрого. 2012. № 3 (13). С. 43-52.

9. Цуркан-Сайфуліна Ю.В. Герменевтичний дискурс права і влади. Вісник Південного регіонального центру Національної академії правових наук України. 2016. № 8. С. 15-22.

10. Шелестов К.О. Праворозуміння та герменевтика. Актуальні проблеми держави і права. 2009. Вип. 50. С. 108-114.

11. Парпан Т. Флексибілізація трудових правовідносин в Україні: очікування та реалії. Вроцлавський-Львівський юридичний збірник. 2019. Вип. 10. С. 159-170.

12. Новіков Д.О., Жукова А.І. Феномен гнучкості трудового права у соціальній філософії. ВісникЗапорізькогонаціональногоуніверситету. Юридичнінауки. 2014. Вип. 2. Ч. 2.С. 194-202.

13. Завацкая Я. «Безусловный основной доход»: «за» и «против». URL: http:// liva.com.ua/basic-income-guarantee.html (дата звернення: 23 липня 2021 р.)

14. Новіков Д.О. Перспективи дослідження теорії «безумовного основного доходу» наукою трудового права. Збірник наукових праць. Серія Право, Харків : ХНПУ ім. Г.С. Сковороди. 2016. Вип. 25. С. 33-41. 